\title{
ARTICLE \\ Fragile environment, fractured citizenship: Environmental displacement and the erosion of citizenship
}

\author{
Nabanita Samanta ${ }^{1}$
}

Accepted: 8 April 2021 / Published online: 23 April 2021

(c) O.P. Jindal Global University (JGU) 2021

\begin{abstract}
The conditions of a fragile and unsustainable ecology have added to the complexities of the much-contested notion of 'citizenship'. Ecological peril, both in the form of extreme weather events and slow-onset impacts of environmental degradation, has serious repercussions for the already prevailing conundrum that the conception of citizenship entails. Proliferation of 'natural' disasters and acceleration of environmental degeneration in recent times have caused large-scale involuntary displacement and consequently a rupture in the sense of 'belonging', which is the cornerstone of citizenship. Thus, it is imperative that the notion of 'citizenship' is reconceptualised in the light of the lived reality of environmental displacement that produces new forms of precarity while disrupting the sense of being-a-citizen. Displacement caused by a fragile and volatile ecology paves the path for a gradual waning of citizenship rights, often leading to loss of avenues for meaningful citizen engagement, thereby making environmental displacement an exemplary case for understanding how 'citizenship' operates as a place-based relation. This article will discuss the precarious conditions of environmentally displaced people and delineate the intractable chasm between the ideas of 'administered' citizenship and 'lived' citizenship. I argue that drawing on 'processual' aspects of citizenship becomes imperative against the backdrop of the rapid degradation of ecosystems which calls for a reworking of the 'political' sphere and a reformulation of the idiom of 'citizenship'.
\end{abstract}

Keywords Citizenship · Environmental displacement · Ecoprecarity · Lived citizenship $\cdot$ Citizenship rights $\cdot$ Spatiality $\cdot$ Materialities of politics

Nabanita Samanta

nabanitasamanta097@gmail.com

1 University of Hyderabad, Hyderabad, India 


\section{Introduction}

The millions of displaced people ... are nothing but refugees of an unacknowledged war.

—Arundhati Roy ${ }^{1}$

As we find ourselves pummelled by the concerns around catastrophic ecological degradation, displacement induced by environmental perils has turned out to be an inescapable fact. The recent upsurge in environmental threats in the form of both extreme weather events (such as floods, cyclones, heat-waves) and slow-onset impacts of environmental degradation (e.g., coastal erosion due to rising sea-levels, depletion of natural resources, desertification) has resulted in large-scale involuntary displacement, and the rate of such environmental displacement will only accelerate amidst the delirium of the 'Capitalocene' era. ${ }^{2}$

Though a problem as complex as environmental displacement can hardly be quantified, the severity of the crisis can be grasped by taking a glance at some staggering statistical figures: for instance, the Ecological Threat Register, a 2020 report published by the Institute for Economics and Peace, a Sydney-based international think-tank, ascertains that ecological disasters displace an average of 24 million people per year and if the current rate continues, there would be at least 1.2 billion people displaced globally by the end of $2050 .{ }^{3}$ The report, while warning that the projected rate of environmental displacement may be far higher in all likelihood, further elucidates that the majority of these displaced people would be displaced within their own country or may be scattered across neighbouring regions in some cases. ${ }^{4}$ Though 'displacement' eludes easy definition, particularly in a context where environmental displacement takes place through processes with varied

\footnotetext{
1 Arundhati Roy, 'The Greater Common Good' (Outlook, 24 May 1999). https://magazine.outlookindia. com/story/the-greater-common-good/207509. Accessed 29 March 2021.

2 The neologism 'Capitalocene', indicative of the material history behind the plaguing climate crisis, has recently gained ground in contrast to Paul J Crutzen and Eugene F Stoermer's labelling of the current epoch as 'Anthropocene'. See Jason W Moore, 'Anthropocene or Capitalocene? Nature, History, and the Crisis of Capitalism' in Jason W Moore (ed), Anthropocene or Capitalocene? Nature, History, and the Crisis of Capitalism (PM Press 2016). The conception of 'Anthropocene', while holding the anthropos as an entire species responsible for cataclysmic climate change, overlooks that in actuality different people have contributed unevenly to the climate crisis (for instance, unevenness in the contribution of the Global North as compared to the Global South is worth mentioning here; it is also important to notice how the contribution to climate crisis and the detrimental effects that it brings often remain disproportionate). It is in this connection that 'Capitalocene' has been thought of as a better way of conceiving the current epoch as the planetary crises reigning in contemporary times can mostly be traced back to the capitalistic economy. Here, in the context of this article, underlining the inconspicuous nexus between planetary crises (like that of unprecedented climate change and consequent ecodisasters) and the functioning of capitalism becomes significant to fathoming the severity of environmental displacement which is likely to worsen further amidst the rapid strides of neoliberal capitalism.

${ }^{3}$ Institute for Economics and Peace, Ecological Threat Register 2020: Understanding Ecological Threats, Resilience and Peace (September 2020) 3. https://reliefweb.int/sites/reliefweb.int/files/resou rces/ETR_2020_web-1.pdf. Accessed 31 March 2021.

${ }^{4}$ Ibid.
} 
ramifications, it can however be argued that the process of 'dis-placement' operates through an embodied, emplaced, and layered experience-experience which, while being affective, remains both public and private at the same time. ${ }^{5}$ While displacement is foisted upon the bodies and psyche of those being displaced, such experiences of corporeal mobility cannot be fully grasped without explicating the entrenched power dynamics and mundane materialities of everyday life. Not only is there an intricate interplay between environmental catastrophes and statecraft, even displaced lives remain inextricably linked with spatialised relations of politics. To explicate this spatialised nature of political relation, this article fixes its analytical gaze on the discourses of citizenship as it will endeavour to bring the conception of citizenship in dialogue with the conditions exacerbating environmental displacement. For lack of primary ethnographic data, ${ }^{6}$ I will attempt to weave my analysis based on a careful scrutiny (primarily looking from a social-anthropological vantage point) of secondary sources, drawing mostly from already existing theories on citizenship which I will re-examine in the light of the challenges posed by environmental displacement.

In classical discourses, citizenship has often been conceived as a legal status or a given identity grounded in a specific set of codified rights. TH Marshall, inheriting the liberal tradition of James Mill and JS Mill, adhered to the substantive, universalist ideals of equality and freedom (in the individualistic connotation of these terms) as the cornerstone for citizenship. ${ }^{7}$ The axial point in Marshall's analysis has been the question of rights, which he conceived in three broad subsets, namely civil rights, political rights, and social rights. ${ }^{8}$ Though Marshall's theory cast a strong spell on scholars and theorists during his time and even in later periods, it has been subjected to much criticism on different grounds-for Marshall's individualistic

\footnotetext{
5 The private-public dichotomy has already been subjected to strong criticisms by feminist scholars. For instance, see Jeff Weintraub and Krishan Kumar (eds), Public and Private in Thought and Practice: Perspectives on a Grand Dichotomy (University of Chicago Press 1997); Chris Armstrong and Judith Squires, 'Beyond the Public/Private Dichotomy: Relational Space and Sexual Inequalities' (2002) 1(3) Contemporary Political Theory 261. Displacement is one such arena which unsettles the public-private dichotomy by altering the perception of space. Displacement, particularly environmental displacement, calls for a different mode of articulation of the question of public-private. Reconceptualising the publicprivate dichotomy in the light of displacement may even pave the way for reorienting the locus of politics.

6 The months-long hiatus brought by the Covid-19 pandemic has severely constrained any such aspiration of carrying out ethnographic research. Methodological innovation in the form of a shift towards digital ethnography has been coming to the fore in the domain of social research. See Annika Lems, 'The (Im)possibility of Ethnographic Research during Corona' (Max Planck Institute for Social Anthropology, 11 June 2020). https://www.eth.mpg.de/5478478/news-2020-06-11-01. Accessed 30 March 2021. However, digital engagement seems inappropriate for the theme that this article deals with. Environmental displacement being a subject of embedded and embodied experience tied to particular localities necessitates immersive research which could not be done given the current context; hence I had to improvise and find alternative ways to concretise the raw ideas which could not be substantiated with empirical observation, and this made me resort to theoretical deliberation to present an analytical and reflective exploration of the theme presented in the form of this review essay.

7 TH Marshall, 'Citizenship and Social Class' in Citizenship and Social Class and Other Essays (Cambridge University Press 1950) 1.

8 Ibid.
} 
leaning and consequent obliviousness towards existing social inequalities, ${ }^{9}$ for treating civil rights and social rights as almost equivalent, ${ }^{10}$ for being 'conservative', ${ }^{11}$ for its 'ethnocentric' 12 orientation, ${ }^{13}$ and so on. More recently, considering the contemporary context, Marshall's theorisation of citizenship has been rendered somewhat obsolete in the face of 'disorganised capitalism' ${ }^{14}$ as Marshall's assumption of 'autonomous' nation-states stands redundant given the thriving world capitalistic system. ${ }^{15}$

Notwithstanding the discontents with the Marshallian tradition, the legacy of the classical tradition continues in the form of a persisting insistence on rights. Even in contemporary discourses, the question of rights receives a great emphasis, rendering the status of citizens contingent upon their holding of rights; however, the depth of citizenship can hardly be fathomed either through codified rights or through the legal status of right-bearers. Instead, what calls for careful discernment is the processual aspect pertaining to citizenship, that is, whether the codified citizenship rights actually get translated into effective entitlements and actual benefits. It is the claim-making abilities of the citizens that become pivotal in translating rights into desirable outcomes or entitlement-benefits. These claim-making abilities in turn remain tied to space and infrastructure (as will be discussed later in this article). It is in this connection that a fragile ecology comes as a major jolt to citizenship entitlements insofar as rapidly degraded ecology and ecodisasters, while leaving spaces fractured and built infrastructures dismantled, often result in the curtailment of the claim-making abilities of citizens.

Given the precarious lives that environmentally displaced people are thrust into, displacement for such people leads to a gradual erosion of the sense of citizenship as well as waning of citizenship rights. This article seeks to provide a brief perusal of how degradation of ecology exacerbates the process of degradation of citizenship.

\footnotetext{
9 Harold J Laski, The Rise of European Liberalism (Aakar Books 2005 [1936]) 214.

10 Anthony Giddens, Profiles and Critiques in Social Theory (Macmillan 1982) 172.

11 Maurice Roche, 'Citizenship, Social Theory and Social Change' (1987) 16 Theory and Society 363, 368.

12 Here 'ethnocentric' orientation points to the fact that Marshall's theory had proven applicable to the then context of capitalistic Britain; however, that does not necessarily mean that it would be applicable to other societies as well.

13 Michael Mann, 'Ruling Class Strategies and Citizenship' (1987) 21(3) Sociology 339, 340. This point has also been underlined by Giddens as he states: 'His [Marshall's] analysis of citizenship and social class was based upon a long-term historical survey, and, being concerned mainly with Britain, Marshall refrained from suggesting that it could be applied en bloc to other countries in Europe, or the USA.' See Giddens, Profiles and Critiques in Social Theory (n 10) 167.

14 Bryan S Turner, 'Outline of a Theory of Citizenship' (1990) 24(2) Sociology 189, 195.

15 The term 'disorganised capitalism' broadly refers to the fragmentation of socio-economic structure under the sway of advanced capitalism. It was political sociologist Claus Offe who elaborated on this concept in his work Disorganized Capitalism: Contemporary Transformations of Work and Politics (Polity Press 1985). Later Scott Lash and John Urry, in their work titled The End of Organised Capitalism (Polity Press 1987), also dealt with the concept of 'disorganised capitalism'. Economic restructuring in the globalised era, while allegedly disrupting the organised interaction between capital and labour, has brought in political disorganisation. Moreover, the growth of global capitalism poses serious obstacles to Marshall's theory which assumes some sort of autonomy for nation-states. As nation-states are no longer immune from the constraints posed by the world-system, Marshall's assumption becomes irrelevant.
} 
To contextualise the intricacies, a snapshot capturing the perils of volatile ecology leading to involuntary displacement will be presented. The article will then attend to the modes and materialities of 'belonging' to explain how conventional ways of thinking about citizenship actually lead to a reification of the concept as it undermines the dynamism of itinerant identities of displaced peoples. As a severed sense of 'belonging' and ruptured representation of 'home' imbricate the very process of experiencing displacement, how a jolt to 'belonging' causes a dwindling of citizenship rights will also be analysed. This will be followed by an attempt to reconceptualise citizenship taking 'ecoprecarity' as the analytic so as to foreground the primacy of ecology in determining political relations.

\section{Volatile ecology, mobile lives: Pervasive precariousness, pernicious challenges}

[C]limate change can be a catalyst for a range of very different and far less desirable forms of social, political, and economic transformation.

$$
\text { -Naomi Klein }{ }^{16}
$$

The response towards climate change often takes the form of indifference and denial by a segment of people-whom Bruno Latour has regarded as the "climate skeptics, ${ }^{17}$ and this particular inclination of denial or dismissal has been termed as "ecological amnesia ${ }^{18}$ by Naomi Klein. ${ }^{19}$ Despite the callousness that Klein has been critical of, anthropogenic climate change is no longer a distant future or dystopian foresight; rather, it is 'an inconvenient truth' ${ }^{20}$ that we are currently grappling with. Well beyond a mere fear-mongering, 'apocalyptic imagination', ${ }^{21}$ the lurking reality of Nature's ${ }^{22}$ fury as unleashed in the form of extreme weather events like torrential rains, devastating floods, spells of heat-waves, and severe droughts is now very much a part of the lived experiences plaguing our times. It is in this planetary conjuncture that almost every realm of life has been in need of revamping as the repercussions of climate change necessitate reconceptualisation of several of the commonplace notions, a few instances of which are as follows.

\footnotetext{
${ }^{16}$ Naomi Klein, This Changes Everything: Capitalism vs. the Climate (Penguin Books 2015) 8.

17 Despite having alarming 'scientific' evidence for climate change happening at an unprecedented rate, the political response to such findings has often been manifested in the form of outright denial. In this context, Latour highlights the waning of trust in the institution of 'science'. See Bruno Latour, $A n$ Inquiry into Modes of Existence: An Anthropology of the Moderns (Harvard University Press 2013) 2.

${ }^{18}$ Klein, This Changes Everything (n 16) 4.

${ }^{19}$ Klein has provocatively argued that we deny the reality of climate change for what constitutes a "crisis' is often determined by power and priorities well beyond the hard facts.

${ }^{20} \mathrm{Al}$ Gore, An Inconvenient Truth: The Planetary Emergency of Global Warming and What We Can Do about It (Rodale 2006).

${ }^{21}$ Paul Hoggett, 'Climate Change and the Apocalyptic Imagination' (2011) 16(3) Psychoanalysis, Culture \& Society 261.

${ }^{22}$ Here, 'Nature' has been capitalised to underline its constructivist character. See Timothy Morton, Ecology without Nature: Rethinking Environmental Aesthetics (Harvard University Press 2007).
} 
Dipesh Chakrabarty has reflected upon the way climate change unsettles the conventional understanding of history by posing several 'contradictions and confusions' mostly due to human beings assuming geological agency in an unprecedented way as a result of which the long-standing idea of temporality stands altered and the conventional conception of history gets upended. ${ }^{23}$ This disruption in the temporal scale has resulted from the conflating of three kinds of histories, namely pre-biotic planetary history, history of evolutionary life, and the history of the industrial era. ${ }^{24}$ Though Chakrabarty has pointed out how these three histories coalesce ${ }^{25}$ it is the third kind of history characterised by unprecedented human activities ${ }^{26}$ leaving an indelible mark on the planet's geology that can be held responsible for exacerbation of the climate crisis.

While Chakrabarty's analysis has underlined the bearings of climate change on the conceptualisation of history and temporality (which in turn opens up new questions regarding how we conceive sociality and politics), Ulrich Beck has brought to the fore the possibilities of nation-states fading into oblivion due to the risks and challenges posed by anthropogenic climate change. ${ }^{27}$ Beck has pointed out how climate change, while defying the geographical boundaries of nation-states, dismantles nation-states as a commonplace category or unit of political action. ${ }^{28}$

The repercussions of climate change have also been spelled out from the vantage point of human rights: the way degraded ecology often leads to curtailment of essential human rights given to people both by international and domestic laws ${ }^{29}$ the way climate change has necessitated substantial restructuring of global governance which in turn calls for rethinking the dominant human rights discourses in terms of considering whether the challenges posed by climate change can be addressed by deploying an existing framework of rights or whether there is a need for conceiving the right to sustainable environment as a 'meta-right'.

All the above-mentioned instances, though divergent in their focus and vantage points, deal with the effects and consequences of climate crisis with the underlying aim of accentuating the need for reconceptualising the sphere of life and politics in the light of rapid degradation of ecology. Needless to say, ecological degradation,

\footnotetext{
23 Dipesh Chakrabarty, 'The Climate of History: Four Theses' (2009) 35(2) Critical Inquiry 197, 206.

24 Dipesh Chakrabarty, 'Climate and Capital: On Conjoined Histories' (2014) 41(1) Critical Inquiry 1.

25 Ibid. 15.

${ }^{26}$ Human activities operating through an interconnected matrix of colonialism, capitalism, and industrialism have not only altered the arrangements of human affairs but also intervened in geological arrangements, as a result of which the divide between natural history and human history stands blurred.

27 Ulrich Beck, 'Emancipatory Catastrophism: What Does It Mean to Climate Change and Risk Society?' (2015) 63(1) Current Sociology 75, 76.

28 Ibid. 76. While pointing to the limitations of 'methodological nationalism', Beck writes: 'climate change induces fundamentally changing landscapes of social class and inequality created through rising sea levels which draw new maps of the world where the key lines are not traditional boundaries between nation-states and social classes, but rather elevation above sea.' Ibid.

29 Sam Adelman, 'Rethinking Human Rights: The Impact of Climate Change on the Dominant Discourse' in Stephen Humphreys (ed), Human Rights and Climate Change (Cambridge University Press 2009) 167.

30 Ibid. 172.
} 
while posing significant challenges to the question of survival, not only jeopardises overall planetary wellbeing but also unsettles many of the conventional understandings of life and living, of politics and sociality. Out of the myriad ways through which the piercing strings of climate change can be felt, displacement is perhaps one of the most perplexing threats that we are confounded with. Environmental displacement occurs as a major fallout from the cascading crises brought to the fore by the pervasiveness of 'ecological melt-down' ${ }^{31}$ reigning in contemporary times. Such an upheaval, while posing substantial challenges to the dynamic materialities ${ }^{32}$ of everyday life, lays bare the loopholes in existing frameworks of analysing relations of sociality and political praxis. Citizenship is one such arena which is in need of rethinking and reorientation in the context of environmental displacement. By bearing the brunt of a fragile and unsustainable ecology, displaced people often lose the avenues of meaningful engagement as citizens or claimants of rights. Thus, it is worthwhile to delineate how ecological volatility, which pushes displaced peoples towards a life of precariousness and vulnerabilities, muddles the much-contested notion of citizenship.

\section{Modes and materialities of 'belonging': Citizenship as lived ontology}

Citizenship is at heart a matrix of institutional relationships, technologies, political idioms, and rights-claiming practices that are always dynamic and contingent.

\section{-Margaret R Somers ${ }^{33}$}

Citizenship has conventionally been understood in terms of a legal status and a set of codified rights. Citizenship has also been conceived as an identity; however, it is significant to note that here 'identity' needs to be understood not as a static category but in terms of a dynamic conception of 'belonging'. In other words, even though citizenship entails an identity, it doesn't constitute an identity in itself, rather it remains as a 'distinctly political identity, one which stipulates the conditions of membership in and exclusion from a political community'. ${ }^{34}$ Thus, citizenship confers an identity by virtue of which inclusion/exclusion in the political community of the state is determined. It is through the conditions for inclusion or exclusion that the provision for making claims on the state can be actualised, thereby actualising protection under the safety net of a welfare state. However, this process of inclusion/exclusion remains far from systematic, in fact it entails continuous negotiation

\footnotetext{
31 George Myerson, Ecology and the End of Postmodernity (Icon Books 2001).

32 By this (in the context of citizenship), I point to the mundane day-to-day affairs through which citizens make claims to the state.

33 Margaret R Somers, Genealogies of Citizenship: Markets, Statelessness, and the Right to Have Rights (Cambridge University Press 2008) 35.

34 Trevor Purvis and Alan Hunt, 'Identity versus Citizenship: Transformations in the Discourses and Practices of Citizenship' (1999) 8(4) Social \& Legal Studies 457, 462.
} 
between claim-making endeavours of citizens on the one hand and the workings of the state on the other. ${ }^{35}$ This negotiation is particularly important in the context of the Global South often characterised by a wide gulf between policy and implementation, between codified rights and substantive realisation of those rights. Claimmaking in the context of citizenship benefits comprises 'citizen action in pursuit of welfare goods and services, which are broadly understood as resources intended to protect and improve the well-being of citizens' ${ }^{36}$ Claim-making abilities constitute ordinary forms of political participation, which remains quintessential (yet often overlooked or undermined ${ }^{37}$ ) for conceptualising citizenship. It is through making claims that the citizens navigate access to the state for securing welfare measures. Such processes of claim-making remain tied to spatialised arrangements and appropriation of local networks. ${ }^{38}$ Spatiality has often been bracketed in the discussions on citizenship, and the question of spatiality has only been taken into account in the case of displacement taking place across borders, mostly because the spatial dimension with regard to the question of citizenship is often seen as coterminous with the border of nation-states (due to the fact that in conventional ways of understanding, citizenship has been conceived as a formal category determining membership in a national polity). However, in the changing context of contemporary times, particularly considering the volatility of ecology, spatiality needs to be conceived at a localised level. To bring in the context of environmental displacement, I will now concentrate on the way citizenship remains contingent on spatial arrangements exemplified through infrastructural interventions.

Infrastructural arrangements, far from being mere mundane material objects, remain a significant means of legitimising inclusion in the ambit of state protection. This entails twin roles: on the one hand, it is through these material arrangements that citizenship appears as embodied forms of negotiation between the state and the citizens, while on the other hand, such material arrangements further consolidate claim-making abilities of the citizens. In this regard, it is relevant to recall Nikhil Anand's acclaimed work on 'hydraulic citizenship' 39 'a form of belonging to the

\footnotetext{
35 Irene Bloemraad, 'Theorising the Power of Citizenship as Claims-Making' (2018) 44(1) Journal of Ethnic and Migration Studies 4.

${ }^{36}$ Gabrielle Kruks-Wisner, Claiming the State: Active Citizenship and Social Welfare in Rural India (Cambridge University Press 2018) 6.

37 Claim-making as apparently mundane affairs of political participation often gets less recognition as compared to electoral participation and taking part in dramatic events like protests or social movements. Yet, these everyday practices, despite their ordinariness, remain essential for understanding how citizenship operates far from being a given status.

38 While talking about local networks, the roles played by non-state actors deserve attention. In the contemporary context, there is a growing role for non-state actors as service-providers or even mediating agents for navigating access to the state. However, given the limited scope of this article, the role of nonstate actors in the affairs of citizenship will not be elaborated here. Moreover, in terms of legitimacy and strength, the role of the state remains pivotal (particularly in the context of the Global South) notwithstanding the challenges posed by globalisation (which has affected the autonomy and influence that the state has enjoyed).

39 Nikhil Anand, Hydraulic City: Water and the Infrastructures of Citizenship in Mumbai (Duke University Press 2017).
} 
city enabled by social and material claims made to the city's water infrastructure'. ${ }^{40}$ Drawing on the analogy of 'power', ${ }^{41}$ Anand has elucidated how citizenship and water-infrastructure constitute each other as citizens negotiate their legitimacy by means of access to regular water services. ${ }^{42}$ Anand has also drawn attention to the materiality of water which has a significant bearing on political formation. ${ }^{43}$

Not just pumps and pipelines (as in the case of water services), most other mundane material arrangements like electricity poles and wires, roads, schools and other government buildings, etc.-all such spatial arrangements stand as symbolic representations of integration and inclusion within the ambit of the welfare state. To put it differently, the built environment, while underscoring the salience of place in the matrix of political relations, accentuates how such places are configured by the jigsaw of power and permeated with the institutions of the state machinery. These material arrangements in a given space operate as a vehicle of power, politics, and legitimacy. ${ }^{44}$

In the context of environmental displacement, degraded ecology and ecodisasters, while rupturing the space of dwelling, also cause the collapse of such 'public' infrastructures which constitute the modes and materialities of 'belonging' to the fold of the welfare state. Thus, environmentally displaced people lose not only their place of residence but also the avenues for continuing the process of negotiation through which citizenship rights get actuated into the required outcomes. As infrastructural arrangements stand as a means for claiming state protection and anchoring belonging, ecodisasters, while bringing demise and disintegration of spatial arrangements, unsettle the modes of 'belonging', which in turn affects the abilities of making claims on the state. It is through the abilities of making claims and negotiating for rights that individuals within a given spatial context acquire legitimacy as 'citizens'. Insofar as such claim-making abilities remain implicated and constituted in their material conditions, the disruption of material and spatial conditions brought by environmental displacement severely fractures the potential of codified rights to be transformed into actual benefits. It is in this sense that degraded ecology and waning of citizenship remain inextricably linked to each other. Citizenship, in this vein of understanding, remains 'processual' 45 _ far from the static, reified 'simulacrum $^{46}$ as it is often conceived in the conventional understanding.

${ }^{40}$ Nikhil Anand, 'The PoliTechnics of Water Supply in Mumbai' (2011) 26(4) Cultural Anthropology 542,545 .

${ }^{41}$ Here, the word 'power' has been deployed in the dual sense of the term: power in the sense of physical determinant or topographic gradient that determines waterflow, and power that is exerted through social relations on settling water-infrastructure.

${ }^{42}$ Anand, Hydraulic City (n 39) 6.

${ }^{43}$ Ibid. 7.

${ }^{44}$ Legitimacy in both ways: the state earns legitimacy (in the Weberian sense of the term) over a territory through infrastructural interventions, which in turn act as a means for citizens to negotiate their belonging to the fold of the state.

${ }^{45}$ Ajantha Subramanian, Shorelines: Space and Rights in South India (Stanford University Press 2009) 19.

${ }^{46}$ Mark Poster (ed), Jean Baudrillard: Selected Writings (2nd edn, Stanford University Press 2001) 169. 
Political discourses are often found to be more inclined towards identity and institution instead of laying emphasis on process and practice; however, focusing the analytical gaze on processual aspects renders intelligible the intractable chasm between 'theoretical' citizenship and 'lived' citizenship. For instance, environmentally displaced people (internally displaced) continue to remain as citizens on paper though their claim-making abilities stand curtailed and their sense of belonging severely fractured. In terms of formal recognition, the displaced individuals are still considered 'citizens' or claimants of rights but their 'right to have rights' ${ }^{47}$ stands eroded. As the materialities of politics crumble in the face of degraded ecology, so does the agency of claim-making which is quintessential to the process of being-acitizen. This often subjects displaced lives to an exclusion that is less visible and a violence that is less perceptible.

\section{4 'Ecoprecarity' and embodied displacement: 'Citizenship' reconsidered}

The relocation of peoples that globalism ignites has disrupted and sullied the idea of home and has expanded the focus of identity beyond definitions of citizenship to clarifications of foreignness.

-Toni Morrison ${ }^{48}$

Inhabiting the Capitalocene comes with an unprecedented condition of precarity as the reign of global neoliberal capitalism catalyses the intensification of deprivation and insecurity. Deteriorating ecology further exacerbates already afflicting precarity. In the context of ecological degradation and ecodisasters, the condition of precarity needs to be understood going beyond the anthropocentric leanings which render precarity intelligible only in terms of the human condition. To avert such shortcomings, it is the conception of 'ecoprecarity' which holds significant valence as much as it seems relevant to deciphering the nuances of displaced lives. For Pramod K Nayar, 'ecoprecarity' is 'at once about the precarious lives humans lead in the event of ecological disaster ... and also about the environment itself which is rendered precarious due to human intervention in the Anthropocene' ${ }^{49}$ Understanding precarity at these twin levels - of humans and of ecology - is significant in order to decipher the complementariness and co-constitutive nature of both.

Understood sociologically, precarity is nothing but an outgrowth of the (in)action entrenched in the socio-political systems of the Capitalocene. The conception of ecoprecarity underlines that politics can no longer be understood outside ecology; neither can ecology be discerned without engaging with the question of politics. It is with the aim of foregrounding the role of ecology in shaping and reshaping political

\footnotetext{
47 Hannah Arendt, The Origins of Totalitarianism (Harcourt Brace Jovanovich 1973) 296.

48 Toni Morrison, The Source of Self-Regard: Selected Essays, Speeches, and Meditations (Vintage International 2019) 21; emphasis in original.

49 Pramod K Nayar, Ecoprecarity: Vulnerable Lives in Literature and Culture (Routledge 2019) 7; emphasis in original.
} 
relation that this article has sought to analyse how the conundrum of citizenship gets aggravated in the context of environmental displacement. The conventional understanding often ends up confining politics to the realm of human activities while overlooking the potential of more-than-human entities in shaping the contours of political relations. Ecology has mostly been conceived as a mere backdrop for sociopolitical relations instead of being an active actor in political processes. Volatile ecology unsettles political relations by posing newer challenges as political relations are mostly place-based in character. Since citizenship exemplifies the centrality of place-based relation in the politico-administrative arena, environmental displacement poses significant challenges to the conception of citizenship. In the context of environmental displacement, ecology does intervene in severely fracturing the claim-making abilities of citizens. Insofar as citizenship remains far from being a given identity, it becomes imperative to step out of anthropocentric leanings to acknowledge the role of ecology in the shaping and reshaping of citizenship. Taking into account the precarity plaguing the ecology will enable us to bring to the fore the intricate interplay between ecology and polity, thereby transcending the anthropocentric bias with which political praxis is often laden.

\section{Concluding remarks}

I make, remake and unmake my concepts along a moving horizon, from an always decentered centre, from an always displaced periphery which repeats and differenciates them.

\section{-Gilles Deleuze ${ }^{50}$}

There are noticeable limitations in the business-as-usual kind of understanding of citizenship in which descent and identity often take precedence as the primary criteria for conferring citizenship rights. Citizenship, when understood in legal and hardened terms, implies bestowing everyone with equal status within the confinement of a national polity. In actuality, as I have argued, citizenship, far from being an already formed or given category, is very much a dynamic affair and remains contingent upon the claim-making process and continuous negotiation which in turn stand implicated in the materiality of socio-natural worlds. Moreover, it is the insistence on rights which characterises most of the conventional discourses on citizenship; but it is important to look at citizenship as an exercise through which codified rights translate into entitlements. This process remains contingent upon the avenues for claim-making which in turn are tied to spatial experiences and exposure. Any disruption of being-in-place simultaneously causes a dwindling of agency insofar as space and agency are constitutive of each other. This has been explicated by pointing to the crumbling of the mundane materialities of political relations which in turn causes waning of citizenship rights. While accentuating the way disruption of spatiality and disintegration of agency get attuned to each other, the question of

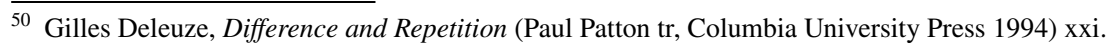


itinerant identities of displaced lives comes to the fore as much as it underscores the conundrum of 'belonging'. Thus, the question of spatiality acquires significant valence in conceptualising citizenship which often takes shape through the spatial arrangements that determine the potential for rights to be translated into entitlementbenefits. Taking up the case of environmental displacement has enabled engagement with the question of spatiality while it has also underlined the need for taking ecology as an active actor in shaping citizenship.

As we hurtle through the insurmountable challenges posed by degraded ecology, the transgression of "planetary boundaries" ${ }^{51}$ one after another indicates that the frequency and extent of ecodisasters are likely to accelerate further. Thus, considering the serious repercussions brought about by the proliferation of disasters and degeneration of ecology, it has become imperative that every sphere of life on earth be reconceptualised taking into account the plaguing perils of degraded ecology. It is in this context that the sphere of politics in general and citizenship in particular seems to be in dire need of reformulation, specifically keeping in view the large-scale involuntary displacements occurring as perplexing fallouts of a fragile ecology. Ecology has mostly been seen as a passive background (bereft of any agency of its own) in matters of citizenship. However, in the face of environmental displacement and rapid degradation of ecology, it has become necessary that ecology is taken as a potent factor in shaping and reshaping the contours of citizenship.

Publisher's Note Springer Nature remains neutral with regard to jurisdictional claims in published maps and institutional affiliations.

${ }^{51}$ Johan Rockstrom, Will Steffen, Kevin Noone, et al., 'Planetary Boundaries: Exploring the Safe Operating Space for Humanity' (2009) 14(2) Ecology and Society 1. 